UMBARA

Indonesian Journal of Anthropology

Volume 5 (1) Juli 2020 || eISSN 2528-1569 | pISSN 2528-2115 || http://jurnal.unpad.ac.id/umbara

DOI : 10.24198/umbara.v5i1.28056

\title{
Peran Organisasi Perempuan dalam Penguatan Social Capital Melawan Pandemi Covid-19 (Studi pada Gerakan Kampanye Sosial Persit Kartika Chandra Kirana XXXIX Kabupaten Pati Jawa Tengah)
}

\author{
Dewi Erowati ${ }^{1}$, Kuncoro Bayu Prasetyo ${ }^{2}$, Sri Astuty ${ }^{3}$, Tutting Anggraeni ${ }^{4}$ \\ ${ }^{1}$ Universitas Diponegoro, Semarang, Indonesia \\ dewi.erowati@live.undip.ac.id \\ ${ }^{2}$ Universitas Negeri Semarang, Indonesia \\ mrbayu@mail.unnes.ac.id \\ ${ }^{3}$ Univesitas Lambung Mangkurat, Banjarmasin, Indonesia \\ sri_astuty@ulm.ac.id \\ ${ }^{4}$ Universitas Diponegoro, Semarang, Indonesia, \\ tuttinganggraeni@students.undip.ac.id
}

\begin{abstract}
The Covid-19 pandemic has spread globally. In Indonesia, when the pandemic destroys the health system and global economy, social capital arrives as an alternative to sustain community resilience. This research aims to 1) describe a social capital within the community and how it is being campaigned and strengthened within the community by the actors in the community itself amidts their effort to overcome the Covid-19 pandemic; and 2) to describe community's response towards the social capital campaign. The study was conducted using qualitative methods. Observation was conducted towards various activism by Persit KCK XXXIX Pati; a women's organizations, in particular their activities in social campaign against Covid-19 pandemic. The results of this research suggest that social capital can be an alternative for community survival when economis capital destroyed. Solidarity and mutual assistance among community members without considering the financial benefits is crucial in a crisis situation of the Covid-19 pandemic. Persit Kartika Chandra Kirana Branch XXXIX Pati through its various voluntary and non-profit activities has shown itself as one of the driving forces for the growth and revitalization of social capital within the community, especially through the networks that they structurally or non-structurally owned.
\end{abstract}

Keywords: Covid-19, pandemic, Persit Kartika Chandra Kirana, social campaign, social capital

\begin{abstract}
Abstrak
Pandemi Covid-19 telah menyebar secara global. Di Indonesia, saat pandemi meluluhlantakkan sistem kesehatan dan perekonomian dunia, maka modal sosial (social capital) merupakan harapan alternatif untuk menopang daya tahan masyarakat. Artikel ini bertujuan menggambarkan eksistensi modal sosial di masyarakat yang dikampanyekan dan diperkuat di kalangan masyarakat oleh para aktor di masyarakat
\end{abstract}


itu sendiri dalam konteks penanggulangan pandemi Covid-19; serta menggambarkan respon masyarakat terhadap gerakan kampanye penguatan modal sosial tersebut. Penelitian dilakukan dengan metode kualitatif. Pengamatan dilakukan pada berbagai aktivisme organisasi perempuan Persit KCK Cabang XXXIX Pati dalam gerakan edukasi dan kampanye sosial melawan Pandemi Covid-19. Hasil penelitian menunjukkan bahwa di saat modal ekonomi hancur, maka modal sosial dapat menjadi alternatif bagi ketahanan hidup masyarakat. Solidaritas dan saling membantu di antara warga masyarakat tanpa memperhitungkan keuntungan finansial yang juga merupakan salah satu karakteristik modal sosial sangat diperlukan pada situasi krisis pandemi Covid-19. Persit Kartika Chandra Kirana Cabang XXXIX Pati melalui berbagai aktivitas voluntary dan non-profitnya telah memperlihatkan diri sebagai salah satu aktor penggerak tumbuhnya modal sosial, terutama yang dibangun melalui jejaring yang dimilikinya secara struktural maupun secara non-struktural.

Kata kunci: Covid-19, kampanye sosial, pandemi, Persit Kartika Chandra, modal sosial

\section{Pendahuluan}

Pandemi Covid-19 telah menyebar ke 210 negara di dunia, termasuk Indonesia. Data Worldometer per tanggal 19 April 2020 menyatakan jumlah penduduk dunia yang terkonfirmasi positif sebanyak 2.345.476 orang, meninggal dunia 161.196 orang, dan yang sembuh 604.606 orang (Worldometer, 2020). Di Indonesia, terhitung sejak pengumuman resmi tanggal 2 Maret 2020, jumlah warga terkonfirmasi positif virus Covid-19 sebanyak 2 orang dan angka ini terus bertambah setiap hari. Berdasarkan data Worldometer, di Indonesia pada tanggal 19 April 2020 yang terkonfirmasi positif sebanyak 6.575 orang, meninggal dunia sebanyak 582 orang, dan sembuh sebanyak 686 orang. Karakteristik penyebaran virus Covid-19 ini memerlukan perhatian serius dari berbagai lapisan masyarakat. Edukasi yang baik dan tepat diperlukan untuk memberikan pemahaman kepada masyarakat mengenai pola penyebaran dan pencegahannya.

Beragam edukasi yang dilakukan oleh berbagai komunitas yang peduli terhadap bahayanya virus Covid-19 telah dilakukan melalui berbagai media seperti membuat audio visual, poster, dan flyer yang berisi himbauan untuk tinggal di rumah (tagar \#dirumah aja), cara mencegah penyebaran virus Covid-19, rajin mencuci tangan, tidak keluar rumah, etika batuk, himbauan tidak mudik, dan sebagainya. Pembuatan konten di media sosial pun beragam. Beberapa konten edukasi dibuat dalam berbagai versi bahasa daerah yang ada di Indonesia dan bertujuan membangkitkan kesada- ran masyarakat memutus mata rantai penyebaran virus Covid-19 secara masif.

Menurut Coleman (1989), modal sosial adalah kemampuan masyarakat untuk bekerja sama, demi mencapai tujuan bersama, di dalam berbagai kelompok dan organisasi. Kegiatan edukasi yang dilakukan oleh masyarakat merupakan bentuk kepedulian masyarakat dalam menghadapi pandemi dan hal ini menjadi salah satu bentuk gambaran modal sosial ( $\mathrm{so-}$ cial capital) di masyarakat Indonesia di masa pandemi Covid-19. Masyarakat menyadari bahwa pandemi hanya bisa dilawan dengan membangkitkan kesadaran bersama dan kerja sama antar pihak, salah satunya melalui kampanye sosial. Kampanye sosial merupakan bagian dari saluran informasi di masyarakat yang dapat diakses oleh masyarakat.

Gerakan kampanye edukasi pencegahan Covid-19 ini juga dilakukan oleh Persit Kartika Chandra Kirana Cabang XXXIX Dim 0718 Koorcab Rem 073 PD IV/Diponegoro yang dalam tulisan ini akan disebut sebagai Persit KCK Cabang XXXIX Pati. Persit KCK Cabang XXXIX Pati merupakan salah satu organisasi sosial perempuan istri anggota TNI-AD. Para anggota organisasi ini tergerak melaksanakan kegiatan-kegiatan sosial bersama masyarakat yang ada di wilayah Kabupaten Pati Jawa Tengah untuk mencegah penyebaran virus Covid-19. Kabupaten Pati juga termasuk se- 
bagai zona merah Covid-19 di Provinsi Jawa Tengah karena berdasarkan data per 17 April 2020 , terdapat 4 orang warga yang positif, 5 orang pasien dalam pengawasan, dan 79 orang dalam pemantauan, serta 2 orang terkonfirmasi positif yang meninggal dunia. Berangkat dari situasi ini, para anggota Persit KCK Cabang XXXIX Pati tergerak untuk turut berperan serta dalam Gerakan Peduli Covid-19. Kegiatan yang dilakukan bertujuan untuk memutuskan mata rantai penyebaran Covid-19. Saat kondisi awal penyebaran Covid-19 mulai terdeteksi di Indonesia, para anggota Persit KCK Cabang XXXIX Pati mulai mengikuti anjuran pemerintah untuk tetap tinggal di rumah, Namun, mereka kemudian menyadari bahwa berada di rumah saja tidak cukup tanpa kontribusi yang nyata di masyarakat. Selanjutnya, para anggota Persit KCK Cabang XXXIX Pati menginisiasi gerakan kampanye untuk membangun kesadaran masyarakat Kabupaten Pati terhadap bahaya penyebaran Covid-19 dengan menghimbau masyarakat agar tetap berada di rumah. Para anggota membuat pamflet, video serta foto yang dipublikasikan melalui media sosial untuk mengedukasi masyarakat tentang bahayanya Covid-19, serta membagikan masker pada masyarakat. Kegiatan kampanye dan edukasi yang dilakukan oleh Persit KCK Cabang XXXIX Pati merupakan gambaran wujud modal sosial dan merupakan bentuk kampanye kesehatan juga sekaligus kampanye sosial.

Artikel ini membahas kegiatan yang dilakukan oleh Organisasi Perempuan Persit KCK Cabang XXXIX Pati sebagai bentuk kampanye kesehatan dan sosial yang sekaligus menggambarkan upaya penguatan modal sosial masyarakat di Pati dalam melawan Pandemi Covid-19.

\section{Kajian Pustaka}

\section{Kampanye: Kampanye Sosial, dan Kam- panye Kesehatan}

Kampanye adalah sebuah upaya yang diorganisasi oleh satu kelompok yang merupakan agen perubahan, dan ditujukan untuk membujuk target sasaran agar bisa menerima, memodifikasi atau membuang berbagai ide, sikap dan perilaku tertentu (Kotler dan Roberto, 1989 dalam Cangara, 2014). Selanjutnya Rogers dan Storey (1987) dalam Venus (2012) juga memberikan definisi kampanye sebagai "serangkaian tindakan komunikasi yang terencana dengan tujuan untuk menciptakan efek tertentu pada sejumlah besar khalayak yang dilakukan secara berkelanjutan pada kurun waktu tertentu". Pada definisi tersebut, maka aktivitas kampanye: (1) bertujuan menciptakan efek atau dampak tertentu; (2) targetnya khalayak sasaran yang besar; (3) dipusatkan dalam kurun waktu tertentu; dan (4) melalui serangkaian tindakan komunikasi terorganisir. Berdasarkan definisi tersebut, maka kampanye dapat diartikan sebagai hal yang dilakukan oleh manusia, dalam hal ini bisa individu, masyarakat, komunitas maupun organisasi, untuk menyebarluaskan pesan-pesan secara persuasif untuk mempengaruhi dan sekaligus menciptakan efek tertentu bagi penerima pesan. Proses komunikasi yang terjadi dalam kegiatan kampanye melibatkan berbagai unsur komunikasi di antaranya pelaku kampanye, pesan kampanye, saluran kampanye, dan khalayak sasaran kampanye. Pesan-pesan kampanye yang disampaikan pada khalayak, akan dicerna dengan cara yang berbeda-beda oleh masing-masing individu yang menerima pesan tersebut, dan kemungkinan pesan tersebut dapat diterima atau ditolak oleh individu atau masyarakat penerima pesan.

Kampanye sosial menurut Venus (2012) adalah aktivitas komunikasi yang dilakukan secara terlembaga yang berarti tersusun dengan adanya individu, masyarakat, atau organisasi yang mempunyai kemampuan menyusun dan merencanakan kampanye secara terarah. Penyelenggara kampanye umumnya adalah lembaga atau organisasi yang berasal dari lingkungan pemerintah, komunitas, kalangan swasta atau lembaga swadaya.

Kampanye sosial juga merupakan berbagai aktivitas yang dilakukan perseorangan atau organisasi dengan terencana dan memiliki tujuan untuk masyarakat. Sejalan dengan Larson (1992) dalam Venus (2012), kampanye 
sosial merupakan kegiatan dalam mengkomunikasikan atau menyampaikan pesan kepada masyarakat tentang berbagai persoalan sosial yang bersifat non komersil. Kampanye sosial terbagi dalam tiga kategori, yaitu 1) product-oriented campaign, 2) candidate-oriented campaign, dan 3) ideologically or cause oriented campaign. Product oriented campaign merupakan kegiatan kampanye yang berorientasi pada produk dan biasanya dilakukan dalam kegiatan komersial, seperti promosi pemasaran suatu peluncuran produk baru. Kategori kedua, yaitu candidate-oriented campaign adalah kegiatan kampanye yang berorientasi bagi calon atau kandidat untuk kepentingan kampanye politik. Selanjutnya, kategori yang ketiga adalah ideological or cause-oriented campaign yaitu kategori kampanye yang berfokus pada tujuan yang bersifat khusus.

Gerakan kampanye kesehatan di masa pandemi Covid 19 yang bisa disebut juga sebagai komunikasi kesehatan, adalah kegiatan edukasi dalam kerangka memutus rantai penyebaran Covid-19. Gerakan ini merupakan bagian dari komunikasi antar individu dengan fokus utama membuat individu mampu menghadapi isu-isu kesehatan yang beragam terkait Covid-19, serta mampu memelihara kesehatannya di tengah derasnya isu hoaks mengenai pandemi yang jumlahnya semakin besar. Berdasarkan data Kominfo dalam laporan per tanggal 18 April 2020, jumlah hoaks mengenai Covid-19 yang telah diverifikasi sebanyak 554. Angka ini menggambarkan besarnya bahaya misinformasi. Oleh karena itu, komunikasi kesehatan untuk melawan Covid-19 perlu dilakukan dan hal ini dapat menjadi gerakan komunikasi kesehatan. Di dalam kampanye ini, pesan-pesan informasi kesehatan yang berasal dari sumber yang kredibel diberikan dan disampaikan secara benar. Kegiatan ini tidak hanya dilakukan pemerintah semata, akan tetapi perlu juga dilakukan oleh masyarakat dan dapat menggambarkan sebuah gerakan yang terbentuk oleh kuatnya modal sosial di masyarakat.

\section{Modal Sosial}

Social capital atau modal sosial, adalah kemampuan masyarakat untuk bekerja sama, demi mencapai tujuan bersama, di dalam berbagai kelompok dan organisasi (Coleman, 1989). Modal sosial memiliki fungsi dalam keberhasilan pembangunan dan perumusan kebijakan (Fathy, 2019). Modal sosial merupakan proses yang dilakukan terus menerus dalam kelompok sosial dengan mengedepankan partisipasi sosial, kepercayaan dan komitmen bersama dalam melaksanakan sesuatu (Ritzer, 2005).

Fukuyama (1995) mengemukakan tiga unsur utama pembentuk modal sosial yaitu trust (kepercayaan), reciprocal (timbal balik) dan interaksi sosial. Sementara menurut Hasbullah, (2006), ada enam unsur pokok dalam modal sosial yaitu: partisipasi, timbal balik (reciprocity), kepercayaan (trust), norma sosial, nilai (value), dan tindakan proaktif. Keberadaan social capital tersebut bersifat tidak kasat mata (less tangible) yang baru dapat dirasakan apabila seorang aktor menjalin relasi-relasi sosial dalam masyarakat (Usman, 2018).

Modal sosial menumbuhkan nilai-nilai bersama dan dapat dijadikan sebagai strategi dalam mempromosikan nilai-nilai sosial yang positif di masyarakat. Nilai-nilai sosial yang positif dapat ditumbuhkembangkan melalui aktivitas komunikasi dalam hal ini kampanye sosial. Di dalam konteks komunikasi dan informasi, modal sosial berperan dalam pemberdayaan masyarakat yang ditandai dengan adanya berbagai kegiatan untuk peningkatan akses warga masyarakat pada informasi, partisipasi, serta penguatan kapasitas organisasi (Usman, 2018). Hal ini berarti bahwa dalam aksi penguatan modal sosial, terdapat aktivitas komunikasi yang dijalankan dengan strategi kampanye.

\section{Komunikasi Kesehatan}

Komunikasi kesehatan, menurut Liliweri (2008) adalah usaha yang dilakukan secara sistematis untuk mempengaruhi secara positif perilaku kesehatan individu dan komunitas masyarakat, dengan menggunakan berbagai

|| Accepted: 21 July 2020 33 
prinsip dan metode komunikasi baik komunikasi interpersonal, maupun komunikasi massa. Selain itu, komunikasi kesehatan juga dipahami sebagai studi yang mempelajari cara menggunakan strategi komunikasi untuk menyebarluaskan informasi kesehatan yang dapat mempengaruhi individu dan komunitas agar dapat membuat keputusan yang tepat berkaitan dengan pengelolaan kesehatan.

Rahmadiana (2012) menjelaskan bahwa komunikasi kesehatan memanfaatkan jasa komunikasi untuk mempengaruhi secara positif perilaku kesehatan individu, keluarga dan komunitas masyarakat. Komunikasi kesehatan meliputi informasi tentang pencegahan penyakit, promosi kesehatan, kebijakan pemeliharaan kesehatan, serta meningkatkan kesadaran individu tentang isu-isu kesehatan, masalah kesehatan, risiko kesehatan, dan solusi kesehatan dengan menggunakan media advokasi, media massa, media hiburan dan internet dengan tujuan meningkatkan dan mempertahankan derajat kesehatan.

Gerakan melawan Covid-19 dalam bentuk kegiatan kampanye sosial supaya terarah dan terencana baik, menurut temuan Sari (2019), harus dilakukan dengan tiga kegiatan utama, yaitu kegiatan pre-event, event, dan post-event. Keberhasilan kegiatan kampanye bukan hanya ditentukan oleh kejelasan pesan, kualitas kreatif dan eksekusi yang baik, tetapi juga ditentukan oleh perencanaan dan strategi pelaksanaan, serta evaluasi yang dilakukan (Sutresna, 2018). Perencanaan ini diperlukan untuk menentukan target audiens, pesan yang tepat, tujuan yang ingin dicapai dan juga mengukur keberhasilannya. Langkah intensif yang mungkin dapat dilakukan adalah melakukan kampanye komunikasi kesehatan agar bisa mengkomunikasikan perilaku bersih dan sehat melalui penanaman perilaku hidup bersih dan sehat (PHBS) sedini mungkin. Perencanaan komunikasi kesehatan untuk penyusunan program kampanye komunikasi PHBS meliputi tahapan: perencanaan dan seleksi strategi, seleksi media dan material, pengembangan materi pesan, implementasi, dan perhitungan implementasi. Model yang diterapkan dalam kampanye komunikasi
PHBS memperhatikan khalayak sasaran yang akan dituju (Wahyudin, 2016).

Bentuk komunikasi kesehatan yang dilakukan oleh komunitas sebagaimana yang dilakukan oleh Persit KCK Cabang XXXIX Pati berupa media advocacy. Media advocacy adalah upaya pemanfaatan media massa yang lebih strategis dan didukung oleh keikutsertaan masyarakat dengan tujuan untuk meningkatkan kebijakan-kebijakan publik yang berkaitan dengan kesehatan (Rahmadiana, 2012).

\section{Metode}

Metode yang digunakan dalam penelitian ini adalah metode kualitatif dengan analisis deskriptif. Peneliti mendeskripsikan pelaksanaan gerakan kampanye baik kampanye kesehatan maupun kampanye sosial yang dilakukan oleh Persit KCK Cabang XXXIX Pati sebagai pengedukasi, dan masyarakat sebagai teredukasi. Data dikumpulkan, dianalisis, serta ditafsirkan, kemudian ditampilkan dalam bentuk narasi didukung dokumentasi kegiatan. Analisis data penelitian dilakukan secara kualitatif-deskriptif. Cara berpikir induktif diterapkan untuk menganalisis berbagai proses aktivitas yang diteliti (Bungin, 2008).

\section{Hasil dan Pembahasan}

Kaum Perempuan merupakan salah satu kelompok sosial yang paling rentan ketika terjadi suatu bencana (Handayani, 2018). Perempuan rawan menjadi korban baik karena faktor kelemahan fisik maupun karena subordinasi yang dikonstruksi secara sosial maupun kultural. Namun, saat ini di tengah wacana kesetaraan gender yang semakin menguat, perempuan tidak hanya sekadar menjadi korban yang paling rentan dalam bencana semata. Perempuan justru tampil menjadi garda depan dalam penanggulangan bencana. Hal ini tampak ketika dalam bencana kemanusiaan global saat ini yaitu pandemi penyakit menular yang disebabkan oleh Coronavirus atau Covid-19, banyak perempuan baik secara individu maupun terorganisir tampil di ruang publik menjadi garda depan dalam perang global melawan virus 
Corona. Banyak dokter-dokter dan perawat perempuan berjibaku di garis depan perang melawan virus Corona.

Di Kabupaten Pati Provinsi Jawa Tengah yang relatif jauh dari hiruk pikuk sorotan media, juga terdapat sejumlah kaum perempuan yang memiliki kepedulian untuk ikut berpartisipasi di ruang publik dalam mengkampanyekan penanggulangan pandemi Covid-19 melalui berbagai komunitas. Salah satunya, adalah para perempuan yang tergabung dalam komunitas organisasi istri Tentara Nasional Indonesia Angkatan Darat (TNI-AD) yang memiliki nama resmi organisasi Persit Kartika Chandra Kirana Cabang XXXIX Dim 0718 Koorcab Rem 073 PD IV/Diponegoro. Secara organisatoris, Persit Kartika Chandra Kirana merupakan organisasi yang memiliki struktur hingga level nasional mengikuti hirarki organisasi TNI-AD. Saat ini, Persit KCK Cabang XXXIX Pati diketuai oleh Ibu Iing Adi Ilham Zamani yang merupakan istri dari Komandan Kodim 0718/Pati, Letkol CZI Adi Ilham Zamani S.E. M.Ip.

Kegiatan Persit KCK Cabang XXXIX Pati dalam gerakan kampanye dan edukasi penanggulangan pandemi Covid-19 cukup menarik dikaji karena semangat volunterisme yang melatarbelakangi gerakan tersebut memanfaatkan berbagai jejaring modal sosial yang mereka miliki. Persit KCK Cabang XXXIX Pati menjadi salah satu aktor institusional yang berperan dalam upaya penanggulangan pandemi Covid-19 di Kabupaten Pati khususnya dalam jalur upaya yang sifatnya preventif. Bentuk upaya preventif ini salah satunya adalah edukasi kepada masyarakat untuk mengkampanyekan informasi tentang bahaya Covid-19 serta kampanye melakukan gerakan hidup sehat agar terhindar dari resiko penularan Covid-19. Gerakan kampanye dan edukasi penanggulangan Covid-19 yang dilakukan oleh Persit KCK Cabang XXXIX Pati tersebut secara sosiologis merupakan upaya partisipatif antar komponen masyarakat dalam mengaktifkan jejaring modal sosial yang telah ada untuk kepentingan suatu tujuan bersama.
Secara lebih terinci hasil riset ini menemukan beberapa data yang menarik dari aktivisme yang dilakukan oleh Persit KCK Cabang XXXIX Pati selama adanya pandemi Covid-19. Modal sosial menjadi aspek yang berperan penting dalam kampanye dan gerakan sosial melawan pandemi ini.

\section{Latar Belakang Keterlibatan Persit KCK Cabang XXXIX Pati dalam gerakan Kam- panye Melawan Covid-19}

Inisiasi awal gerakan sosial yang dilakukan oleh Persit KCK Cabang XXXIX Pati dalam kegiatan penanggulangan dimulai dari ide ketua organisasi, yaitu Ibu Iing Adi Ilham Zamani. Menurut penuturan Ibu Iing, awal mula gerakan yang dilakukan oleh Persit KCK Cabang XXXIX Pati ini dilandasi oleh adanya keprihatinan terhadap situasi Pandemi Covid-19 yang semula terjadi di Wuhan China, tetapi secara cepat membesar menjadi pandemi global yang menyerbu segala penjuru belahan dunia, tidak terkecuali di Indonesia. Imbas dari Pandemi Covid-19 juga telah merambah Kabupaten Pati, bahkan telah menimbulkan korban jiwa dari berbagai kalangan. Salah satu korbannya adalah anggota DPR RI yang juga seorang tokoh masyarakat di Kabupaten Pati yang meninggal dunia pada akhir Maret 2020, beberapa hari setelah melakukan bakti sosial pembagian masker di beberapa wilayah Kabupaten Pati. Namun, meskipun demikian, ternyata kesadaran akan bahaya dari penularan virus Covid-19 belum sepenuhnya tertanam pada sebagian masyarakat Kabupaten Pati. Hal ini terbukti dari tetap ramainya beberapa titik keramaian yang ada di Pati seperti di restoran, café, dan alun-alun kota Pati yang masih didominasi kawula muda untuk berkumpul.

Keprihatinan Ibu Iing Adi Ilham dilanjutkan dengan kegiatan organisasi perempuan yang dipimpinnya. Ia menginisiasi gerakan edukasi dan membangun kesadaran masyarakat Kabupaten Pati agar lebih menyadari mengenai bahaya virus Covid-19.

"Dengan semakin mewabahnya Covid-19, kami di Persit memutuskan untuk mengadakan kegiatan sosialisa- 
si maupun edukasi yang dilakukan baik melalui media maupun terjun langsung ke masyarakat untuk membantu pemerintah Pati dalam melawan Covid-19 atau memutuskan tali rantai penyebaran Covid-19." (Wawancara dengan Ibu Iing Adi Ilham, 19 April 2020)

Upaya merealisasikan gerakan kampanye dan edukasi mengenai virus Covid-19, pertama-tama dilakukan dengan melalui tahap perencanaan. Rencana awal dalam melakukan kegiatan kampanye dan edukasi Covid-19 diawali dengan ide dari Ibu Iing Adi Ilham Zamani yang didiskusikan dengan Ibu Lila Yahudi, istri dari Danramil 01 Pati Kota. Kegiatan ini melibatkan seluruh pengurus Persit KCK Cabang XXXIX Pati dan komunitas-komunitas yang ada di Pati, di antaranya adalah Women's Crisis Center Pati dan Komunitas Perkumpulan Penyandang Disabilitas Indonesia (PPDI) Cabang Pati.

Diskusi mengenai rencana kegiatan dilakukan melalui rapat kecil di Whatsapp grup dan video conference. Di dalam perencanaan tersebut diidentifikasi masalah yang paling mendesak untuk ditindaklanjuti terkait aksi penanggulangan pandemi Covid-19 di wilayah Pati. Hasil diskusi para pengurus Persit KCK Cabang XXXIX Pati beserta komunitas mitra menemukan bahwa masalah terbesar yang mereka hadapi adalah masih rendahnya kesadaran masyarakat Kabupaten Pati terhadap ancaman bahaya Covid-19. Bagi sebagian warga Pati, Covid-19 dianggap penyakit yang ada di kota besar sehingga tidak terlalu mengkhawatirkan karena Kabupaten Pati terletak jauh dari kota besar. Persepsi sebagian masyarakat tersebut tentu saja berpotensi menyebabkan aksi penanggulangan Covid-19 di Pati tidak berjalan maksimal. Oleh sebab itu, kampanye untuk membangun kesadaran publik terhadap bahaya penularan virus Covid-19 menjadi prioritas pertama. Prioritas berikutnya dari perencanaan program adalah mendukung kerja gugus tugas penanggulangan Covid-19 yang telah terbentuk strukturnya hingga ke desa-desa.

\section{Bentuk-Bentuk Kampanye Sosial sebagai Aktivitas Penyadaran Publik}

Kampanye untuk membentuk kesadaran publik terhadap bahaya pandemi Covid-19 yang dilakukan oleh Persit KCK Cabang XXXIX Pati dilakukan dalam berbagai cara. Kegiatan tersebut dapat diklasifikasikan menjadi empat kategori yaitu: 1) kampanye melalui pamflet di jejaring media sosial; 2) pembuatan dan pembagian masker; 3) kampanye melalui video edukasi; dan 4) bakti sosial ke masyarakat. Secara lebih detail bentuk bentuk kegiatan tersebut dapat dijelaskan berikut ini:

\section{Kampanye melalui Media Pamflet dan Jejaring Media Sosial}

Kegiatan ini dipilih sebagai kegiatan perdana dalam upaya kampanye dan edukasi penyadaran masyarakat tentang bahaya Coronavirus atau Covid-19 sebagai bentuk dukungan terhadap gerakan global maupun gerakan nasional untuk mengkampanyekan masyarakat agar melakukan social distancing dan lebih banyak tinggal di rumah. Tema pamflet yang pertama dibuat adalah kampanye gerakan untuk tetap tinggal di rumah dengan mempopulerkan tagar \#dirumahaja dan \#dirumahdulu.

Proses pembuatan pamflet dengan foto ini dilakukan pada Jumat 27 Maret 2020 dengan meminta bantuan staf penerangan Kodim 0718/ Pati untuk layout dan editing selebaran. Pamflet ini ditujukan untuk mengedukasi masyarakat untuk tetap di rumah dan melakukan aktifitas belajar, bekerja dan beribadah di rumah saja. Pamflet ini dikirim oleh penerangan Kodim Pati ke media sosial seperti Instagram dan Facebook serta disebar ke seluruh Whatsapp grup komunitas-komunitas yang ada di wilayah Pati. Pamflet ini juga dikirim ke seluruh anggota Persit KCK Cabang XXXIX Pati melalui Whatsapp grup dan juga dibagikan kepada masyarakat secara lebih luas.

Kampanye melalui pamflet di media sosial ternyata mendapatkan respon yang baik dari masyarakat. Penyebaran pamflet pun dilanjutkan dan disebar melalui platform digital seperti Facebook, Whatsapp dan Instagram. Beberapa seri pamflet berikutnya yang telah dibuat dan dipublikasikan antara lain pamflet dengan tema, “Ayo Lawan Covid 19 Bersama Kita Bisa” yang 
dibuat pada 3 April 2020. Konten pamflet ini adalah ajakan untuk rajin cuci tangan, makan makanan bergizi, menggunakan masker, dan olahraga yang teratur. Pada 13 April 2020, pamflet kembali dibuat untuk mengkampanyekan "Gerakan Memakai Masker: Demi Keselamatan Bersama Mari Saling Melindungi’. Pamflet ini dibuat setelah adanya instruksi daripemerintahuntuk mengenakan masker bagi semua masyarakat yang keluar rumah. Himbauan mengenakan masker sangat perlu dikampanyekan karena pada waktu sebelumnya, himbauan masker hanya ditujukan kepada orang yang sakit. Ketika terjadi perubahan strategi penanggulangan, maka perubahan itu harus tersosialisasi dengan baik.

\section{Kampanye melalui Pembuatan dan Pemba- gian Masker}

Salah satu cara untuk mengendalikan laju persebaran dan penularan Covid-19 menurut protokol yang dikeluarkan oleh badan kesehatan dunia atau WHO adalah penggunaan masker bagi semua saat beraktivitas serta menjaga jarak (CNN Indonesia, 2020). Oleh sebab itu Persit KCK Cabang XXXIX Pati memiliki gagasan untuk membuat masker dan membagikannya kepada masyarakat. Pilihan aktivitas tersebut didorong oleh keinginan untuk membantu mengatasi krisis kelangkaan masker medis yang harganya merajalela paska ditemukannya kejadian penularan Covid-19 di Indonesia. Krisis masker tersebut membuat harga masker medis di pasaran meningkat hingga lebih dari 10 kali lipat, sehingga menyulitkan masyarakat mendapatkannya.

Proses pembuatan masker kain dilakukan mulai tanggal 4 April 2020 dengan memberdayakan anggota Persit KCK Cabang XXXIX Pati yang memiliki kemampuan dan aktivitas konveksi atau menjahit. Salah satu anggota Persit tersebut adalah Ibu Sulari yang bertempat tinggal di Kecamatan Tlogowungu. Proses pembuatan tahap pertama sebanyak 600 masker kain dilakukan dalam waktu 3 hari. Bahan dasar kain untuk masker dibeli dari pabrik kain yang ada di Kecamatan Juwana. Adapun pola atau desain yang dibuat didapatkan dari media Youtube. Kebutuhan anggaran untuk pembuatan masker tersebut mendapatkan dukungan dari Kodim 0718 Pati.

Masker kain yang telah diproduksi, pada tahap pertama dibagikan kepada para prajurit TNI di lingkungan Kodim 0718/Pati yang bertugas di lapangan. Selain sebagai bentuk kepedulian terhadap petugas lapangan yang memiliki risiko tinggi, hal tersebut juga sebagai bentuk kampanye kepada masyarakat. Para prajurit TNI memberikan contoh pemakaian masker agar masyarakat memiliki kesadaran untuk menggunakan masker.

Pada tahap selanjutnya, masker kain diproduksi dengan jumlah yang lebih banyak sehingga dapat dibagikan kepada masyarakat di wilayah Kabupaten Pati yang membutuhkan. Masker tersebut diberikan bersama bantuan lainnya yang berupa nasi bungkus kepada para petugas dan relawan gugus penanggulangan Covid di level desa di wilayah Kabupaten Pati. Bantuan juga diberikan pada masyarakat umum, khususnya kaum perempuan yang terpaksa masih harus bekerja di luar rumah karena harus mencari nafkah (lihat gambar 2) Upaya tersebut mendapatkan apresiasi yang baik dari masyarakat. Upaya ini ternyata juga lebih menyadarkan masyarakat untuk memiliki kewaspadaan dan berpartisipasi secara bersama-sama menanggulangi pandemi Covid-19.

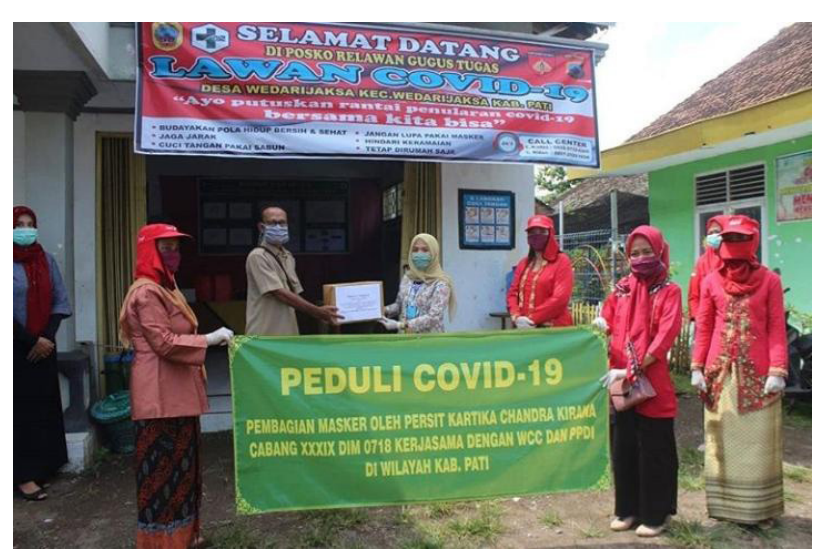

Gambar 1. Kegiatan Edukasi dan Kampanye di 20 Desa Wilayah Kabupaten Pati 


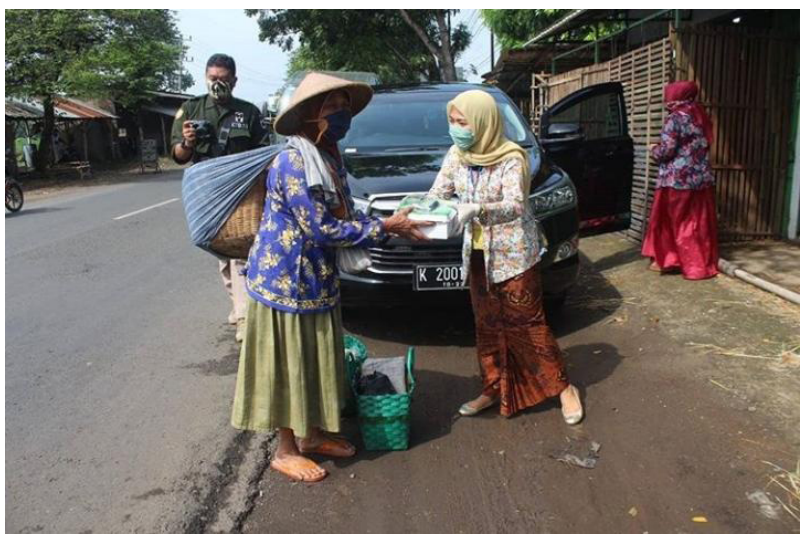

Gambar 2. Interaksi dengan Pekerja Perempuan untuk Memberi Bantuan dan Mengedukasi Penanggulangan Pandemi

\section{Kampanye melalui Pembuatan Video Edukasi}

Media video saat ini menjadi media yang menarik untuk menjangkau banyak khalayak. Media ini juga lebih mudah dipublikasikan serta disosialisasikan karena hampir semua orang saat ini memiliki smartphone dan akun media sosial. Oleh sebab itu, kampanye dan edukasi melalui video juga menjadi salah satu strategi Persit KCK Cabang XXXIX Pati dalam gerakan ini. Ada beberapa serial video yang telah dibuat sejak 14 -17 April 2020. Video dirancang berdurasi pendek kurang dari 1 menit agar dapat ditayangkan di Instagram dan dikirim melalui platform Whatsapp secara lebih mudah dan ringan.

Video pertama dibuat dengan model vlog langsung oleh Ketua Persit KCK Cabang XXXIX Pati, Ibu Iing. Video berisikan edukasi untuk menghindari penularan Covid-19 antara lain dengan selalu berolahraga meskipun di rumah seperti yang sedang dilakukannya saat melakukan pembuatan vlog. Ia juga menganjurkan agar masyarakat menjaga imunitas tubuh serta menerapkan pola hidup bersih dan sehat terutama mencuci tangan dan tidak memegang wajah.

Video lain dibuat dengan tujuan memberikan apresiasi para tenaga medis yang telah berjuang di garda depan menangani para pasien Covid-19. Video itu juga bertujuan meningkatkan motivasi para tenaga medis, sekaligus mengedukasi masyarakat bahwa penyakit Covid-19 sangat serius. Masyarakat harus betul- betul memiliki kesadaran dan kedisiplinan yang baik serta tidak meremehkannya. Video tersebut dibuat dengan melibatkan para anggota Persit KCK Cabang XXXIX Pati dan telah disebarkan kepada masyarakat di wilayah Kabupaten Pati melalui berbagai jejaring digital, terutama Youtube, Whatsapp, Instagram dan Facebook.

\section{Bakti Sosial kepada Masyarakat Kabupaten} Pati

Selain kegiatan kampanye dan edukasi yang dilakukan melalui platform media digital, Persit KCK Cabang XXXIX Pati juga melakukan kegiatan secara langsung di lapangan dengan jangkauan masyarakat yang lebih luas. Kegiatan lapangan tersebut dilakukan dalam bentuk bakti sosial dengan beberapa sasaran.

Kegiatan bakti sosial yang pertama dilakukan pada tanggal 21 April 2020 bertepatan dengan peringatan Hari Kartini. Kegiatan ini dilakukan Persit KCK Cabang XXXIX Pati dengan berkolaborasi bersama Women's Crisis Center (WCC) Pati dan Perkumpulan Penyandang Disabilitas Indonesia (PPDI) Cabang Pati. Bakti sosial ini dilakukan dalam bentuk pemberian bantuan masker kepada lima desa di wilayah Pati, yaitu: Kutoharjo, Trangkil, Kajen, Wedarijaksa dan Panggungroyom. Ketua WCC Pati, Ibu Yanti dan Ketua PPDI Pati, Bapak Suratno turut terlibat langsung dalam kegiatan bakti sosial ini sebagai bentuk sinergi antar organisasi sosial di wilayah Kabupaten Pati.

Kegiatan bakti sosial dilanjutkan pada hari Rabu tanggal 22 April 2020 dengan melakukan pembagian 100 nasi kotak kepada tukang becak, tukang parkir, bakul sayur dan pedagang keliling, serta ojek online yang ada di beberapa titik wilayah Pati. Selanjutnya, bakti sosial yang lain dilakukan pada hari Kamis 23 April 2020 dengan memberikan bingkisan kepada para tenaga medis di puskesmas dan rumah sakit yang ada di wilayah Kabupaten Pati.

Respon dan Tanggapan Masyarakat Pati terhadap Gerakan Kampanye Persit Kartika Chandra Kirana XXXIX Pati

Masyarakat Pati merespon dengan positif kegia- 
tan-kegiatan yang sudah dilakukan oleh Persit KCK Cabang XXXIX Pati. Masyarakat terbantu atas edukasi yang diberikan melalui pamflet dan video. Masyarakat mengharapkan kegiatan-kegiatan yang dilakukan tidak hanya sekali tapi terus menerus. Masyarakat yang terlibat langsung dalam gugus tugas di pedesaan juga merasa senang karena diperhatikan. Mereka bahkan menjadi lebih semangat dalam kampanye dan turut memberi penyadaran kepada masyarakat di wilayah masing-masing. Hal tersebut diungkapkan salah seorang informan yang juga menjabat kepala Desa Wedarijaksa, Bapak Bambang Priyanto (52 tahun):

\section{"Saya sebagai Kepala Desa merasa bergembira dengan adanya kegiatan yang dilakukan Persit KCK Cabang XXXIX Kodim Pati di desa kami, seperti pembagian masker yang pasti bermanfaat bagi warga desa kami dan akan lebih menyadarkan masyarakat desa kami tentang kewaspadaan ter- hadap virus Corona." (Wawancara dengan Bapak Bambang, kepala Desa Wedarijaksa, 21 April 2020)}

Pembagian makan siang juga mendapatkan respon positif dari masyarakat pekerja harian yang terdampak seperti tukang ojek, tukang becak dan penyapu jalanan. Salah seorang informan yang berprofesi sebagai pengemudi ojek online merasa sangat terbantu karena di saat ini pendapatannya menurun drastis. Bantuan tersebut dapat meringankan pengeluarannya untuk makan siang. Hal tersebut disampaikan Bapak Budi Susilo (40 tahun):

"Saya dan para pekerja harian lain-
nya merasa sangat terbantu dengan
bakti sosial yang dilakukan ibu-ibu
Persit Kodim Pati karena mampu se-
dikit mengurangi beban, karena saat
ini pendapatan kami menurun sangat
drastis." (Wawancara dengan Bapak
Budi, pengemudi ojek online, 22
April 2020)

Kegiatan yang dilakukan oleh Persit juga mendapat respon positif dari media massa lokal, salah satunya adalah Radio Past FM di
Pati. Radio itu memberitakan kegiatan- kegiatan kampanye dan edukasi Persit KCK Cabang XXXIX Pati dan mewawancarai langsung Ketua Persit Ibu Iing. Efek pemberitaan inilah yang terus menggaungkan proses kampanye dan edukasi penanggulangan Covid-19 kepada masyarakat Pati.

\section{Kampanye Melawan Covid-19 sebagai Upa- ya Penguatan Modal Sosial}

Di dalam upaya melawan persebaran Covid-19 di Kabupaten Pati, ternyata partisipasi masyarakat maupun organisasi-organisasi sosial yang ada di masyarakat sangat berdampak baik. Organisasi sosial menjadi agen yang efektif dalam melakukan kampanye dan edukasi bagi masyarakat luas terhadap fenomena pandemi Covid-19, yang notabene merupakan sebuah fenomena penyakit baru dan sebelumnya tidak banyak dikenal oleh masyarakat. Kekuatan-kekuatan organisasi sosial yang bergerak tanpa tendensi ekonomi ini merupakan sebuah kekuatan modal sosial yang sangat berharga dan dibutuhkan dalam kehidupan sosial. Kekuatan modal sosial ini mampu menjadi sarana yang efektif untuk mengelola, meningkatkan dan mendayagunakan relasi-relasi sosial untuk memperoleh manfaat sosial (Usman, 2018).

Fenomena pandemi Covid-19 telah membuat modal sosial menjadi tampak nyata ketika berbagai komponen masyarakat bahu-membahu saling mengingatkan dan membantu dalam upaya penanggulangan dampak pandemi Covid-19. Seperti halnya yang dikatakan oleh Usman (2018), bahwa pada dasarnya modal sosial bersifat tidak kasat mata (less tangible), dan baru dapat dirasakan keberadaannya atau dapat diidentifikasi gejalanya ketika mulai terbangun jalinan relasi-relasi sosial yang digerakkan oleh sebuah tujuan tertentu. Dengan demikian, fenomena pandemi Covid-19 telah menjadi trigger atau pemicu tampaknya modal sosial pada masyarakat Pati dalam relasi sosial yang terbangun melalui kampanye dan edukasi penanggulangan Covid-19.

Di dalam fenomena gerakan kampanye dan edukasi penanggulangan Covid-19 yang dilakukan oleh Persit KCK Cabang XXXIX 
Pati, modal sosial terbangun ketika jejaring atau network dikembangkan untuk memfasilitasi relasi-relasi sosial, baik dalam bentuk ikatan atau bonding, bridging atau menjembatani, maupun linking atau menghubungkan. Modal sosial tersebut tebentuk melalui networking antara Persit KCK Cabang XXXIX dengan Kodim 0718/Pati, Kepala Desa, Women's Crisis Center, PPDI maupun masyarakat luas.

Mengacu pada pendapat Bourdieu dalam Muhamad, Bintarsih, dan Yusar (2017), modal sosial akan terus direproduksi dalam kehidupan masyarakat. Konteks sosial dan kebutuhan masyarakat akan menentukan bagaimana proses reproduksi modal sosial berlangsung. Modal sosial secara latency telah ada dalam kehidupan masyarakat Pati. Modal sosial tersebut kemudian direproduksi kembali untuk kepentingan kampanye melawan wabah penyakit Covid-19.

Proses kampanye sosial dengan melakukan modal sosial tersebut terjadi pada tiga unsur utama modal sosial sebagaimana dijelaskan Fukuyama (1995) yaitu trust (kepercayaan), reciprocal (timbal balik) dan interaksi sosial. Trust atau kepercayaan terjadi di antara Persit KCK Cabang XXXIX Pati, organisasi sosial mitra seperti PPDI dan Women's Crisis Center, serta kalangan masyarakat dan tokoh masyarakat yang menjadi sasaran gerakan kampanye dan edukasi. Semuanya saling mempercayai bahwa semua hal yang dilakukan adalah dalam rangka kebaikan bersama yaitu penanggulangan pandemi Covid-19.

Aspek resiprokal juga terjadi karena pihak yang terlibat dalam kegiatan saling mendapatkan manfaat. Pihak Persit KCK Cabang XXXIX Pati yang dalam pandangan awam terlihat lebih banyak memberikan donasi sebenarnya juga mendapatkan manfaat timbal balik karena aktivitas yang dilakukan tersebut juga sekaligus menjadi kampanye membangun kesadaran bagi para anggotanya untuk lebih peduli dengan pandemi Covid-19. Sementara aspek interaksi sosial sebagai pembentuk modal sosial juga terjadi baik dalam ranah interaksi fisik maupun interaksi virtual melalui kampanye dan edukasi di media sosial maupun media massa.

\section{Simpulan}

Di dalam upaya perang melawan pandemi Covid-19 peranan modal sosial menjadi sangat penting karena serangan Covid-19 telah meluluhlantakkan berbagai sendi sosial ekonomi masyarakat. Covid-19 tidak saja menjadi problem medis, tetapi juga menjadi masalah besar dalam kehidupan sosial ekonomi. Upaya terbaik yang bisa dilakukan untuk mengatasi pandemi Covid-19 adalah memutus mata rantai persebarannya dengan mengurangi aktivitas dan interaksi manusia. Tentu saja upaya tersebut harus dibayar mahal dengan terhentinya banyak gerak roda ekonomi, sehingga banyak masyarakat yang terhenti pekerjaannya, bahkan kehilangan mata pencaharian dan berkurang penghasilannya.

Di saat modal ekonomi hancur, maka modal sosial dapat menjadi alternatif bagi ketahanan hidup masyarakat. Solidaritas dan saling membantu tanpa memperhitungkan keuntungan finansial yang juga merupakan salah satu karakteristik modal sosial sangat diperlukan pada situasi krisis pandemi Covid-19. Kampanye sosial yang dilakukan oleh Persit KCK XXXIX Kabupaten Pati merupakan wujud dari beroperasinya modal sosial sekaligus merupakan salah satu sarana dalam penguatan modal sosial yang secara latency telah ada dalam kehidupan masyarakat di Kabupaten Pati. Persit KCK Cabang XXXIX Pati melalui berbagai aktivitas voluntary dan non-profitnya telah memperlihatkan diri sebagai salah satu aktor penggerak tumbuhnya modal sosial melalui jejaring yang dimilikinya secara struktural dengan unsur pemerintah daerah, yaitu melalui Kodim sebagai bagian dari institusi Forkopimda (Forum komunikasi pimpinan daerah) maupun secara non-struktural dengan lembaga sosial lainnya seperti Women's Crisis Center dan Perkumpulan Penyandang Disabilitas Indonesia (PPDI).

\section{Daftar Pustaka}

Bungin, B. (2008). Penelitian Kualitatif: Komunikasi, Ekonomi, Kebijakan Publik dan Ilmu Sosial Lainnya. Jakarta: Kencana Prenada Media Group. 
Cangara, H. (2014). Komunikasi Politik: Konsep, Teori, dan Strategi (Edisi Revisi). Jakarta: Rajawali Pers.

CNN Indonesia. (2020). WHO Kini Dukung Semua Orang Pakai Masker Cegah Covid-19. Dirujuk April 5, 2020, dari https://www.cnnindonesia.com/internasional/20200405061442-134-490399/who-kinidukung-semua-orang-pakai-masker-cegahcovid-19

Coleman, J. (1989). Social Capital in Creation of Human Capital. Chicago: University of Chicago Press.

Fathy, R. (2019). Modal Sosial: Konsep, Inklusivitas dan Pemberdayaan Masyarakat. Jurnal Pemikiran Sosiologi, 6(1), 1-17.

Fukuyama, F. (1995). Trust: The Social Virtues and The Creation of Prosperity. New York: The Free Press.

Handayani, B. L. (2018). Memperkuat Modal Sosial Perempuan dalam Menghadapi Bencana. Journal of Urban Sociology, 1(1).

Hasbullah, J. (2006). Social Capital (Menuju Keunggulan Budaya Manusia Indonesia). Jakarta: MR-United Press.

Liliweri, A. (2008). Dasar-dasar Komunikasi Kesehatan. Jakarta: Pustaka Pelajar.

Muhamad, T., Bintarsih, S., dan Yusar. (2017). Modal Sosial dalam Penanggulangan Bencana Banjir (Kasus di Kabupaten Bandung, Jawa Barat). Sosioglobal: Jurnal Pemikiran Dan Penelitian Sosiologi, 1(2), 101-114.

Rahmadiana, M. (2012). Komunikasi Kesehatan: Sebuah Tinjauan. Jurnal Psikogenesis, 1(1), 88-94.

Ritzer, G. (2005). Teori Sosiologi Modern. Jakarta: Prenada Media.

Sari, D. K. (2019). Kampanye Sosial Red Readerhood 2019 untuk Meningkatkan Minat Baca Anak. Jurnal Sains Pemasaran Indonesia, 18(1), 81-103.

Sutresna, A. (2018). Analisis Perencanaan Kampanye Pemasaran Sosial "Kobarkan Kebaikan" Pertamina. Jurnal UltimaComm, 10(2), 177-191.

Usman, S. (2018). Modal Sosial. Yogyakarta: Pustaka Pelajar.

Venus, A. (2012). Manajemen Kampanye Panduan Teoretis dan Praktis dalam Mengefektifkan Kampanye Komunikasi Edisi Revisi. Bandung: Simbiosa Rekatama Media.
Wahyudin, U. (2016). Membangun Model Kampanye Komunikasi Kesehatan PHBS di Jawa Barat. Jurnal Ilmu Politik Dan Komunikasi, 4(2), 27-37.

Worldometer. (2020). Coronavirus Update. Dirujuk April 19, 2020, dari https://www.worldometers.info/coronavirus/ 